\title{
BIOTRANSFORMATION OF DOMESTIC WASTEWATER TREATMENT PLANT SLUDGE BY TWO-STAGE INTEGRATED PROCESSES -LSB \& SSB
}

\author{
MD. Zahangir Alam ${ }^{1,2 *}$, A. H. MOLla ${ }^{2,3}$, A. FAKHrU'L-RAZI ${ }^{2}$ \\ ${ }^{1}$ Bioenviromental Engineering Research Unit (BERU), Department of Biotechnology \\ Engineering, International Islamic University Malaysia, Jalan Gombak, 53100 Kuala Lumpur. \\ ${ }^{2}$ Department of Chemical and Environmental Engineering, Faculty of Engineering, University \\ Putra Malaysia, 43400 UPM Serdang, Selangor, Malaysia. \\ ${ }^{3}$ Department of Crop Botany, Bangabandhu Sheikh. Mujibur Rahman Agricultural University, \\ Salna, Gazipur 1706, Bangladesh. \\ e-mail: zahangir@iiu.edu.my
}

\begin{abstract}
The study of biotransformation of domestic wastewater treatment plant (DWTP) sludge was conducted in laboratory-scale by two-stage integrated process i.e. liquid state bioconversion (LSB) and solid state bioconversion (SSB) processes. The liquid wastewater sludge [ $4 \% \mathrm{w} / \mathrm{w}$ of total suspended solids (TSS)] was treated by mixed filamentous fungi Penicillium corylophilum and Aspergillus niger, isolated, screened and mixed cultured in terms of their higher biodegradation potential to wastewater sludge. The biosolids was increased to about $10 \% \mathrm{w} / \mathrm{w}$. Conversely, the soluble [i.e. Total dissolve solid (TDS)] and insoluble substances (TSS) in treated supernatant were decreased effectively in the LSB process. In the developed LSB process, $93.8 \mathrm{~g} \mathrm{~kg}^{-1}$ of biosolids were enriched with fungal biomass protein and nutrients (NPK), and $98.8 \%$ of TSS, $98.2 \%$ of TDS, $97.3 \%$ of turbidity, $80.2 \%$ of soluble protein, $98.8 \%$ of reducing sugar and $92.7 \%$ of chemical oxygen demand (COD) in treated sludge supernatant were removed after 8 days of treatment. Specific resistance to filtration $\left(1.39 \times 10^{12} \mathrm{~m} / \mathrm{kg}\right)$ was decreased tremendously by the microbial treatment of DWTP sludge after 6 days of fermentation. The treated biosolids in DWTP sludge was considered as pretreated resource materials for composting and converted into compost by SSB process. The SSB process was evaluated for composting by monitoring the microbial growth and its subsequent roles in biodegradation in composting bin (CB). The process was conducted using two mixed fungal cultures, Trichoderma harzianum with Phanerochaete chrysosporium 2094 and (T/P) and T. harzianum and Mucor hiemalis (T/M); and two bulking materials, sawdust (SD) and rice straw (RS). The most encouraging results of microbial growth and subsequent solid state bioconversion were exhibited in the RS than the SD. Significant decrease of the $\mathrm{C} / \mathrm{N}$ ratio and germination index (GI) were attained as well as the higher value of glucosamine was exhibited in compost; which clearly implied that the increased bioconversion occurred in the treated process. Comparatively, superior composts were produced by T/P at 50-60 days of SSB. Significantly lower heavy metals $(\mathrm{Pb}, \mathrm{Cd}, \mathrm{Cr}, \mathrm{Ni}, \mathrm{Cu}$ and $\mathrm{Zn})$ were recorded in chemical analysis of the end products (composts) after SSB, in comparison to the USA's recognized limits for application in municipal solid waste (MSW).
\end{abstract}


Keywords: Liquid state bioconversion, solid state bioconversion, domestic wastewater sludge, filamentous fungi, biosolids and compost.

\section{INTRODUCTION}

The treatment and disposal of domestic wastewater sludge, which are mainly of organic origin, pose one of the most serious challenges all over the world. Proper operation, maintenance and appropriate technology are essential for future waste management strategies to overcome these challenges by efficient utilization of sludge disposal.

Bioconversion i.e, biological-based treatment of wastewater sludge is probably the only way that could lead to sustainability and environmental friendly, and seems to be an immediate solution to these problems. Although there exist many alternatives for sludge treatment and disposal such as landfill, incineration, physical-chemical process, physicochemical process, adsorption, membrane process. None of them are environmental friendly or non-hazardous, every one is disseminating some sort of contaminants to the environment as well as ground water $[1,2]$. In recent years, interest has twisted to the methods/processes based on resource recovery approach known as recycling and utilization of organic materials from sludge. The concept of organic matter recovery by applying biological-based treatment is becoming more popular to be applied for various purposes. Composting as a resource recovery is becoming a more acceptable alternative for sludge treatment due to its potential use for land application as biofertilizer and soil conditioner [3].

Bio-transformation of domestic wastewater treatment plant sludge by liquid state and solid state bioconversion (LSB \& SSB) is being proposed to solve these problems. Considering the existing treatment processes, the employment of fungal treatment using LSB \& SSB is a new approach for the biodegradation, bioseparation, biosolids accumulation, biotransformation or bioremediation of soluble and insoluble organic and/or inorganic substances of DWTP sludge which exhibits the benefit of being non-hazardous and environmental-friendly for all living beings $[4,5]$. The processes were developed with sterilized and semi-sterilized conditions in the laboratory.

In LSB process, the filamentous fungi isolated from wastewater and DWTP sludge [6] entrap the solid particles in higher strength of sludge $(\leq 4 \% \mathrm{w} / \mathrm{w}$ of TSS) during their growth and enhance the biosolids accumulation, bioseparation and biodegradation of treated supernatant $[7,8]$. In LSB treatment, sludge particles are compacted by filamentous mycelia that modify the prose structure of the treated sludge and enhance its filterability and dewaterability [9]. After liquid state bioconversion of the DWTP sludge, the separated fungal biomass containing biosolids generated during the treatment of sludge that was used as composting materials for rapid and effective composting by solid state bioconversion (SSB) process [5]. It contains large content of organic matters, macro- and micro-nutrients and existing high potential microbes for quick bioconversion. The treated supernatant can be disposed without any further treatment as it meets the standard values of discharge [10].

Solid state bioconversion, a biological based process, is well known as a novel low cost promising bioremediation technique [11]. The SSB has been traditionally practiced in composting of agricultural wastes for mushroom cultivation and production of organic 
acids. The process often brings about an improved quality of substrate and enhances the nutritional quality of products [12]. Furthermore, the process offers faster degradation of the substrate due to more homogeneous distribution of excreted enzymes by filamentous fungi [13]. The treatment of wastewater sludge by LSB and SSB has not been widely investigated. Therefore, the present study was undertaken to evaluate the two-stage integrated process for biotransformation, biosolids accumulation and bioseperation of DWTP sludge into a value added product (compost).

\section{MATERIAL AND METHODS}

\subsection{Microbial strains for LSB and SSB processes}

The fungal strains of Aspergillus niger SCahmA103 (IMI385267) and Penicillium corylophilum WWZP1003 (IMI385277) were evaluated for LSB process based on performances of a series of experiments of isolation/identification [6], screening [14] and compatible mixed cultures [15]. The A. niger and $P$. corylophilum strains were isolated from sludge cake and wastewater, respectively and optimized on the basis of potential performance for the treatment of DWTP sludge using LSB process. Two mixed fungal cultures, Trichoderma harzianum with Phanerochaete chrysosporium 2094 and Trichoderma harzianum with Mucor hiemalis were used for SSB process. Among these three strains, T. harzianum and M. hiemalis were isolated from local relevant sources [16] while the last one was collected from lab stock. These strains were found as compatible in mixed culture [17] and adapted to higher percentage of DWTP sludge-rich growing media [18]. The cultures were maintained on $3.9 \% \mathrm{w} / \mathrm{v}$ of potato dextrose agar (PDA, Oxoid) slants, subcultured once in a month and stored at $4^{0} \mathrm{C}$.

\subsection{Collection and preparation of DWTP sludge and bulking materials}

For LSB, the DWTP sludge of 1-2\% w/w of TSS (pH 6.7) was collected from an aeration tank in Indah Water Konsortium (IWK)'s domestic wastewater treatment plant, Kuala Lumpur, Malaysia. The sludge concentration of $4 \%$ w/w of TSS was prepared by removing of the excess free water with the solid/water mass balance. The final $\mathrm{pH}$ recorded in the concentrated sludge $(4 \% \mathrm{w} / \mathrm{w})$ was 6.5 . The sludge medium $(4 \% \mathrm{w} / \mathrm{w}$ of TSS) supplemented with co-substrate of $2 \% \mathrm{w} / \mathrm{w}$ of wheat flour (WF, optimized cheap carbon source) was used throughout the study.

The moisture was recorded around $90 \% \mathrm{w} / \mathrm{w}$ of the biosolids for composting in the SSB process. The sawdust was collected from a local sawmill and a rice straw from

Malaysian Agricultural Research and Development Institute (MARDI). Sawdust was cured for three days followed by sieving with $2.38 \mathrm{~mm}$ and the rice straw was cut into 3-4 $\mathrm{cm}$ followed by milling in bar mill to reduce its size to $0.5 \mathrm{~cm}$ to $3 \mathrm{~cm}$. The biosolids (for $\mathrm{SSB}$ ) were also cured for several days at ambient temperature to reduce moisture content of $90 \% \mathrm{w} / \mathrm{w}$ to $55 \% \mathrm{w} / \mathrm{w}$. The final moisture content recorded was $18.00 \%$ and $7.04 \%$ for the sawdust (SD) and the rice straw (RS), respectively. 


\subsection{Experimental procedures for the LSB Process}

The optimized inoculum and bioconversion process were used to develop the sludge treatment technique in a batch fermenter. The optimized carbon source (C) of wheat flour as co-substrate and the process conditions were used as in Alam et al. [19]. To evaluate the microbially treated biosolids as pretreatment resource materials for rapid and effective composting in developed conditions, a 6-liter capacity BIOSTAT ${ }^{\circledR} \mathrm{CT}$ compact laboratoryscale fermenter (B. Braun Biotech International) with a 5-liter working volume was used. The fermenter was a vertical glass cylinder with the height/diameter ratio of 2.2:1. The fermenter and all its parts were sterilized to be used along with the substrate at $1.5 \mathrm{bar}_{\mathrm{g}}$ and $121^{\circ} \mathrm{C}$ for $45 \mathrm{~min}$. Filtered air was supplied into the substrate in the fermenter just below the impeller by an air compressor. The initial $\mathrm{pH}$ of the substrate was adjusted to 5.5 but it was not controlled thereafter. Temperature, agitation and aeration rate were maintained automatically bya microprocessor controller in the fermenter. An experiment was carried out in the fermenter containing $3 \mathrm{~kg}$ sludge of $4 \% \mathrm{w} / \mathrm{w}$ of TSS content supplemented by $2 \% \mathrm{w} / \mathrm{w}$ of co-substrate (wheat flour). The treatment was started by inoculating $2 \% \mathrm{v} / \mathrm{w}$ of spore suspension of mixed inoculum of $A$. niger and $P$. corylophilum (1:1 ratio of individual) for 10 days (sampling of every two days interval). The concentration of mixed inoculum of A. niger and $P$. corylophilum used were $2 \times 10^{4}$ and $1.25 \times 10^{4}$ spores $/ \mathrm{ml}$ respectively. Inoculum preparation (spore suspension) was done according to the method of Alam et al. [15].

\subsection{Experimental procedures for the SSB Process}

The SSB process was conducted to evaluate the feasibility of the SSB process of DWTP sludge by considering the performance of microbial growth and its subsequence affect on biodegradation. A study was conducted with three inocula and two bulking agents. The experiment was carried out in a plastic composting bin [H $35 \mathrm{~cm}, \mathrm{D}$ (upper) $32 \mathrm{~cm}$ and D (bottom) $25 \mathrm{~cm}$ ] at semi sterile condition. Three inoculations, two bulking agents, and a total of six treatments were conducted to evaluate the composting process with seven harvests $0,5,15,30,45,60$ and 75 days after inoculation. The mixed inoculum of $6 \%(\mathrm{v} / \mathrm{w})$ of spore/mycelial suspension (1:1 ratio of each in mixed inoculum) was used to inoculate the substrate. Equal volumes of mycelial suspension of $P$. chrysosporium 2094 were mixed with their compatible partner. The inocula were prepared according to the procedure of Molla [5]. The concentration of inoculum was $3.28 \times 10^{3}$ and $2.99 \times 10^{3}$ spores/ml for T. harzianum and M. hiemalis, respectively.

Two bulking materials, sawdust and rice straw, were used individually with fungal treated biosolids for the SSB process. Mixed biosolids (55\% moisture, 32.6\% C and 3.6\% $\mathrm{N})$ with sawdust $(18 \%$ moisture, $44 \% \mathrm{C}$ and $0.1 \% \mathrm{~N})$ for preparation of biosolids-sawdust substrate using in the ratio $1: 1$. Similar ratio was also followed to mix biosolids with rice straw $(7.04 \%$ moisture, $49.4 \% \mathrm{C}$ and $0.44 \% \mathrm{~N})$ for biosolids-rice straw substrate. A $3 \mathrm{~g}$ of $\mathrm{KH}_{2} \mathrm{PO}_{4}, 0.3 \mathrm{~g}$ of $\mathrm{MgSO}_{4}$ and $0.3 \mathrm{~g}$ of $\mathrm{CaCl}_{2}$ were used as available nutrients dose per $\mathrm{kg}$ of substrate for the initial activation of inoculated fungi. The amount $(1.9 \mathrm{~g}$ for biosolidsawdust and $1.5 \mathrm{~g}$ for biosolid-rice straw per $100 \mathrm{~g}$ of substrate) of available carbon source, WF as co-substrate was determined to maintain the $\mathrm{C} / \mathrm{N}$ ratio 30:1. In both substrates, $65 \%$ moisture was adjusted as optimum for effective operation of the SSB process. In composting bin, $6 \mathrm{~kg}$ of biosolids-saw dust and $3 \mathrm{~kg}$ of biosolids-rice straw 
substrates were used. The $\mathrm{pH}$ and final moisture content were adjusted for the substrate after autoclaving at $121^{\circ} \mathrm{C}$ for $50 \mathrm{~min}$. The substrates were inoculated with $6 \%$ mixed spores/mycelial suspension. The composting bins were in a shade house for 75 days at ambient temperature $\left(28 \pm 2^{0} \mathrm{C}\right)$. At every harvest, a stick was used for mixing the substrate in a composting bin.

\subsection{Chemical analysis and parameters studied}

The dry biosolids (sludge cake) was collected by filtering the fermentation broth (treated sludge) and dried at $105^{\circ} \mathrm{C}$ for $48 \mathrm{~h}$. The supernatant was used for analysis after centrifuging the fermented broth at $3000 \mathrm{rpm}$ for $30 \mathrm{~min}$. The standard methods [20] were followed for analyzing TS, TSS, and COD. The optical density (OD) of the supernatant was measured at $660 \mathrm{~nm}$ against distilled water in an UV spectrophotometer (UVIKON 933) that was considered as turbidity. Soluble protein was determined according to Lowry method [21]. Total dissolved solids (TDS) was determined by using EC (electrical conductivity)/TDS meter (Hanna Instruments, HI 9835) according to manual instructions of Hanna Instruments. Reducing sugar was measured according to the method of DNS [22]. Total organic carbon (TOC) was measured according to the method of Navarro et al. [23]. Total nitrogen was determined by micro-kjeldahl method [24]. Heavy metals determination was followed by aqua regia extraction method [25]. The sample preparation and calculation for specific resistance to filtration (SRF) test was determined according to Carman [26].

The compost material after harvesting was used for chemical and physical analysis. The analysis was done by using dry compost and its water extract. The sample was dried (at $105^{\circ} \mathrm{C}$ for $24 \mathrm{~h}$ ) in an oven for dry basis calculation. The water extract was collected by adding distilled water to substrate $(10: 1 \mathrm{v} / \mathrm{w})$ followed by a three hour shaking at $180 \mathrm{rpm}$ in orbital shaker at room temperature. Finally the filtrate was collected after filtration through whatman no. 1 filter paper. The TOC, total nitrogen and heavy metals of dry compost were determined as same method as in the LSB process. Glucosamine and germination index were measured from water extract to evaluate the performance of fungal growth \& multiplication, and the level of maturity of compost through biodegradation by SSB, respectively. Glucosamine was determined according to Zheng and Shetty [27]. Germination index was measured by using seeds of Brasicca napus based on the procedure of Zucconi et al. [28].

\subsection{Statistical analysis.}

The experiment was conducted using a completely randomized design with three replicates. The data were analyzed by $\mathrm{F}$ factor after ANOVA, and comparisons means were done separately using the statistical package MSTAT-C [29]. The standard deviation was presented in respective tables. 


\section{RESULTS AND DISCUSSION}

\subsection{Liquid state bioconversion process}

\subsubsection{Biosolids accumulation, biodegradation and bioseparation of DWTP sludge.}

The production of dry biosolids (DBS) enriched with the protein, nutrients and trace elements in treated DWTP sludge using mixed fungal inocula of $A$. niger and $P$. corylophilum is presented in Table 1. The results shown in Table 1 shows that the maximum composting materials (biosolids) production of $93.8 \mathrm{~g} \mathrm{~kg}^{-1}$ was recorded from its initial concentration of $40 \mathrm{~g} \mathrm{~kg}^{-1}$ of liquid sludge after 8 days of fungal treatment. The production rate was slightly declined during final days of treatment (10 days). It might be due to the nature of growth curve of treated microbes in death phase. The DWTP biosolids increased with fungal treatment was used as pretreated resource materials for rapid and effective composting by solid state bioconversion (SSB) process [5]. The fungal treated biosolids improved with nutrients (NPK) and trace elements that could make as the richer composting material compared to other composting materials (sewage sludge, municipal solid wastes, paper sludge, etc) are shown in Table 2. The reports on increasing sludge cake/biosolids in different waste materials of its bioconversion using fungi have been cited by several researchers $[8,30,31]$.

Table 1: Bisolids accumulation, protein enrichment, macro- and micro-elements and $\mathrm{C} / \mathrm{N}$ ratio in fungal treated biosolids as pretreatment material for composting with different fermentation period.

\begin{tabular}{lllllll}
\hline Biosolids, proteins, & \multicolumn{5}{c}{ Treatment period } \\
\cline { 2 - 7 } $\begin{array}{l}\text { nutrients and trace } \\
\text { elements }\end{array}$ & Day 0 & Day 2 & Day 4 & Day 6 & Day 8 & Day 10 \\
\hline${ }^{\mathrm{a} B i o s o l i d s ~}\left(\mathrm{~g} \mathrm{~kg}^{-1}\right)$ & $40.0 \pm 2.10$ & $59.0 \pm 2.07$ & $74.7 \pm 2.50$ & $85.6 \pm 3.20$ & $93.8 \pm 2.70$ & $92.2 \pm 2.10$ \\
bProtein $\left(\mathrm{g} \mathrm{kg}^{-1}\right)$ & $16.7 \pm 1.10$ & $19.9 \pm 0.93$ & $24.1 \pm 0.60$ & $28.3 \pm 0.38$ & $30.2 \pm 0.73$ & $30.1 \pm 1.23$ \\
$\mathrm{C} / \mathrm{N}$ & 7.30 & 7.10 & 6.90 & 6.90 & 7.00 & 7.10 \\
$\mathrm{~N}\left(\mathrm{~g} \mathrm{~kg}^{-1}\right)$ & $48.3 \pm 0.22$ & $53.0 \pm 0.82$ & $59.4 \pm 0.44$ & $60.8 \pm 0.11$ & $61.4 \pm 0.09$ & $62.3 \pm 0.85$ \\
$\mathrm{P}\left(\mathrm{g} \mathrm{kg}^{-1}\right)$ & $19.9 \pm 0.49$ & $26.7 \pm 1.20$ & $26.7 \pm 0.92$ & $28.6 \pm 1.10$ & $30.1 \pm 0.42$ & $31.5 \pm 0.65$ \\
$\mathrm{~K}\left(\mathrm{~g} \mathrm{~kg}^{-1}\right)$ & $0.8 \pm 0.01$ & $01.5 \pm 0.05$ & $01.5 \pm 0.10$ & $01.4 \pm 0.01$ & $01.63 \pm 0.00$ & $01.5 \pm 0.10$ \\
$\mathrm{Fe}\left(\mathrm{g} \mathrm{kg}^{-1}\right)$ & $09.3 \pm 0.40$ & $08.9 \pm 0.24$ & $08.2 \pm 0.11$ & $09.0 \pm 0.03$ & $09.9 \pm 0.07$ & $09.3 \pm 0.07$ \\
$\mathrm{Ca}\left(\mathrm{mg} \mathrm{kg}^{-1}\right)$ & $01.4 \pm 0.02$ & $01.4 \pm 0.03$ & $01.2 \pm 0.02$ & $01.6 \pm 0.03$ & $01.7 \pm 0.17$ & $02.1 \pm 0.02$ \\
$\mathrm{Mn}\left(\mathrm{mg} \mathrm{kg}^{-1}\right)$ & $490 \pm 10.4$ & $390 \pm 30.7$ & $300 \pm 12.20$ & $420 \pm 25.50$ & $540 \pm 10.00$ & $480 \pm 20.10$ \\
$\mathrm{Na}\left(\mathrm{mg} \mathrm{kg}^{-1}\right)$ & $200 \pm 7.50$ & $660 \pm 110$. & $430 \pm 40.80$ & $560 \pm 20.40$ & $450 \pm 10.90$ & $440 \pm 40.00$ \\
$\mathrm{Cu}\left(\mathrm{mg} \mathrm{kg}^{-1}\right)$ & $73.0 \pm 2.50$ & $62.0 \pm 7.10$ & $61.0 \pm 5.00$ & $70.0 \pm 3.40$ & $92.0 \pm 4.40$ & $87.0 \pm 10.1$ \\
$\mathrm{Zn}\left(\mathrm{mg} \mathrm{kg}^{-1}\right)$ & $302 \pm 52.5$ & $300 \pm 41.2$ & $300 \pm 72.10$ & $300 \pm 61.40$ & $310 \pm 32.50$ & $305 \pm 22.00$ \\
$\mathrm{~Pb}\left(\mathrm{mg} \mathrm{kg}^{-1}\right)$ & $32.0 \pm 5.20$ & $28.0 \pm 1.10$ & $28.0 \pm 1.50$ & $29.0 \pm 4.10$ & $43.0 \pm 2.20$ & $36.0 \pm 2.50$
\end{tabular}


${ }^{\mathrm{a}}$ Accumulated biosolids by LSB was determined in $\mathrm{g} \mathrm{kg}^{-1}$ of liquid DWTP sludge (4\% w/w of TSS), ${ }^{b}$ Protein enrichment was determined in $\mathrm{g} \mathrm{kg}^{-1}$ of dry biosolids. All heavy metals analysis were done in dry wet basis.

The protein was also enriched with fungal biomass during microbial treatment of DWTP sludge. Enriched protein in biosolids containing fungal biomass is shown in Table1. Increasing trend of protein in biosolids followed similar trend of biosolids production, as it was determined from biosolids. A maximum of $30 \mathrm{~g}$ of protein was determined in per $\mathrm{kg}$ of dry biosolids of treated sludge after 8 days of treatment. Extensive researches have been done in food and animal husbandry industry for protein enrichment [12], where as very little works were conducted to convert the waste materials into valueadded product with enrichment of protein by microbial treatment [8].

Chemical characterization of compost is generally based on two criteria, agronomic value and heavy metal contents. With regards to the agronomic value, the availability of major elements such as $\mathrm{N}, \mathrm{P}, \mathrm{K}$ and trace elements e.g. $\mathrm{Cu}, \mathrm{Zn}, \mathrm{Mn}, \mathrm{Fe}, \mathrm{Ni}, \mathrm{Ca}$, and $\mathrm{Na}$ must be evaluated [32]. The nutrient values $(\mathrm{N}, \mathrm{P}, \mathrm{K})$ were determined in DWTP sludge to evaluate the quality of composting materials. The microbial effect on nutrient enrichment is shown in Table 1 . The results shown in this study reveal that initial values of nutrients were increased up to final days of fungal treatment. In untreated sludge (control), N, P, and $\mathrm{K}$ were recorded with $48.27,19.87$ and $0.82 \mathrm{~g} \mathrm{~kg}^{-1}$, which were increased to 62.34 , 31.47 and $1.49 \mathrm{~g} \mathrm{~kg}^{-1}$ of dry biosolids, respectively after 10 days of fungal treated sludge. The increased protein in sludge cake has been examined by several authors [8]. The total crude protein is positively correlated with total nitrogen content and fungal biomass, the total $\mathrm{N}$ may increase due to enrichment of fungal biomass in biosolids. The increases in total $\mathrm{N}$ have been observed in many other composting processes [33].

Table 2: Properties of different composting materials compared to treated biosolids of DWTP sludge.

\begin{tabular}{lcccc}
\hline Parameters & \multicolumn{4}{c}{ Composting raw materials (wastes) } \\
\cline { 2 - 5 } & $\begin{array}{c}{ }^{\mathrm{a}} \text { Treated } \\
\text { biosolids } \\
\text { by LSB }\end{array}$ & ${ }^{\mathrm{b}}$ Seawge Sludge & ${ }^{\mathrm{c}} \mathrm{MSW}$ & ${ }^{\mathrm{d}} \mathrm{DPS}$ \\
$\mathrm{C}(\%)$ & 43.4 & 44.5 & 18.6 & \\
$\mathrm{~N}(\%)$ & 6.2 & 9.7 & 1.1 & 40 \\
$\mathrm{C} / \mathrm{N}$ & 7.0 & 4.6 & 16.8 & 0.3 \\
$\mathrm{P}(\%)$ & 3.0 & 2.3 & 0.9 & 135.6 \\
$\mathrm{~K}\left(\mathrm{mg} \mathrm{kg}^{-1}\right)$ & 1530 & - & 5200 & 0.1 \\
$\mathrm{Ca}\left(\mathrm{mg} \mathrm{kg}^{-1}\right)$ & 2005 & - & 6800 & 1.3 \\
$\mathrm{Mn}\left(\mathrm{mg} \mathrm{kg}^{-1}\right)$ & 540 & 278 & 486.3 & 12300 \\
$\mathrm{Na}\left(\mathrm{mg} \mathrm{kg}^{-1}\right)$ & 450 & - & 207 & - \\
$\mathrm{Cu}\left(\mathrm{mg} \mathrm{kg}^{-1}\right)$ & 92 & 726 & 10.3 & 1013 \\
$\mathrm{Zn}\left(\mathrm{mg} \mathrm{kg}^{-1}\right)$ & 310 & 4038 & 110 & 35 \\
\hline
\end{tabular}

DWTP - Domestic Wastewater Treatment Plant; MSW- Municipal Solid Waste; DPS - De-inking

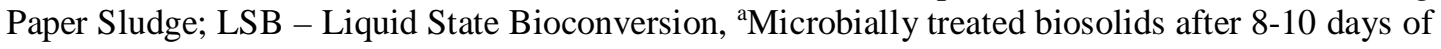


DWTP sludge treatment; chemical analysis were done in dry basis, ${ }^{b}$ Fang et al. [49]; ${ }^{\mathrm{c}}$ Soumare et al. [32]; ${ }^{\mathrm{d}}$ Charest and Beauchamp [50].

Total heavy metals recorded in biosolids after microbial treatment of DWTP sludge with different fermentation time is shown in Table 1 . The initial value of $\mathrm{Ca}$ in biosolids without treatment recorded was $1.4 \mathrm{mg} \mathrm{kg}^{-1}$ and it was increased to $2.1 \mathrm{mg} \mathrm{kg}^{-1}$ after 10 days of fungal treatment. The maximum increase of the trace elements $\mathrm{Ca}$ and $\mathrm{Na}$ were $43 \%$ and $115 \%$ respectively, compared to its initial values ( 0 days, control) in microbially treated biosolids. However, the obtained data are not followed any uniform trends in terms of fermentation period (Table 1), while in most cases, trace elements were slightly increased in fungal treated sludge. Biosolids were enriched with fungal biomass, which has higher biosoption capacity for metals, and might adsorb metals from treated supernatant and perhaps it increased the metals content [34, 35]. Moreover, it was also slightly decreased with different fermentation time. Compared to the different waste composting materials such as municipal solid waste (MSW), citrus waste, sewage sludge and manure, the mineral content in microbially treated biosolids as pretreated material for composting was lower $[32,36,37]$.

In composting process, the $\mathrm{C} / \mathrm{N}$ ratio is a very important factor for compost maturity. As the product biosolids as well as pretreated materials were converted into compost, the $\mathrm{C} / \mathrm{N}$ ratio in biosolids was recorded after LSB of DWTP sludge (Table 1). The $\mathrm{C} / \mathrm{N}$ ratio can be increased to $>25$ from the recorded value of about 7 by the adjustment of carbon contained bulking substances for composting by SSB process.

The biodegradation of the DWTP sludge supernatant during microbial growth recorded was very important because the supernatant was disposed directly to the environment as it meets the standard values of discharge [10]. The total suspended solids (TSS), the total dissolved solids (TDS), reducing sugar as substrate utilization, soluble protein as nitrogen content, optical density at $660 \mathrm{~nm}$ as turbidity, and the chemical oxygen demand (COD) were determined in treated supernatant to evaluate the LSB process for the treatment of the DWTP sludge. The results indicated that the filamentous fungi significantly $(\mathrm{P}>0.05)$ influenced on reduction of TSS, TDS, reducing sugar (RS), soluble protein (SP), optical density (OD) and COD in supernatant of treated sludge and enhanced the LSB process (Table 3). The higher reduction rate was recorded at day 6-8 of the LSB treatment period and no significant difference was observed thereafter. The filamentous fungi entrapped the suspended solid particles in the sludge and enhanced the TSS reduction process significantly $[8,30]$. During treatment, the fungal strains utilized the dissolved substances as food and energy sources in sludge and enhanced the reduction of TDS, SP, and RS of treated sludge [8] In the treatment, the fungal cultures utilized the soluble suspended matters resulting in higher reduction of turbidity. The COD was an important factor to evaluate the organic content of the DWTP sludge. The results suggested that COD removal was highly accelerated by the microbial treatment of the sludge. Fungal growth and its secondary metabolites helped to reduce the soluble and insoluble organic substances in sludge effectively [8]. COD removal of waste materials by fungal treatment have been studied by many authors and they found that COD were reduced by mixed culture of Aspergillus niger, Penicillium corylophilum; Aspergillus awamori and Trichoderma reesei; and single culture of Penicillium spp., Aspergillus oryzae and Rhizopus oligosporus in domestic wastewater [7], olive mill wastewaters [31], and starch processing wastewater [30] with a considerable values (60-90\%). 
Table 3: Biodegradation and bioseparation of DWTP sludge by the mixed culture of $A$. niger and $P$. corylophilum.

\begin{tabular}{|c|c|c|c|c|c|c|c|}
\hline \multirow{3}{*}{$\begin{array}{l}\text { Treatment } \\
\text { period } \\
\text { (day) }\end{array}$} & \multicolumn{7}{|c|}{ Increased biodegradability in supernatant and filterability of treated biosolids } \\
\hline & \multicolumn{5}{|c|}{$\mathrm{g} \mathrm{L}^{-1}$} & \multirow{2}{*}{$\begin{array}{c}\text { Optical } \\
\text { density } \\
(660 \mathrm{~nm}) \\
\text { for } \\
\text { turbidity }\end{array}$} & \multirow{2}{*}{$\begin{array}{c}\text { Specific } \\
\text { resistance } \\
\text { to } \\
\text { filtration } \\
\left(\mathrm{R} \times 10^{12}\right. \\
\mathrm{m} / \mathrm{kg})\end{array}$} \\
\hline & COD & $\mathrm{RS}$ & TDS & SP & TSS & & \\
\hline 0 & $1.28 \pm 0.03$ & $12.9 \pm 0.16$ & $5.5 \pm 0.01$ & $0.33 \pm 0.01$ & $8.10 \pm 0.21$ & $0.85 \pm 0.01$ & $85.45 \pm 2.10$ \\
\hline 2 & $0.96 \pm 0.02$ & $9.2 \pm 0.18$ & $3.7 \pm 0.11$ & $0.25 \pm 0.01$ & $5.86 \pm 0.20$ & $0.71 \pm 0.00$ & $65.21 \pm 2.08$ \\
\hline 4 & $0.66 \pm 0.05$ & $6.3 \pm 0.29$ & $1.6 \pm 0.17$ & $0.19 \pm 0.02$ & $3.10 \pm 0.17$ & $0.11 \pm 0.02$ & $42.37 \pm 0.18$ \\
\hline 6 & $0.22 \pm 0.03$ & $3.8 \pm 0.24$ & $0.2 \pm 0.18$ & $0.09 \pm 0.01$ & $0.50 \pm 0.16$ & $0.05 \pm 0.01$ & $1.39 \pm 0.12$ \\
\hline 8 & $0.15 \pm 0.01$ & $1.4 \pm 0.19$ & $0.1 \pm 0.01$ & $0.07 \pm 0.01$ & $0.09 \pm 0.00$ & $0.02 \pm 0.02$ & $1.58 \pm 0.22$ \\
\hline 10 & $0.09 \pm 0.01$ & $0.4 \pm 0.01$ & $0.1 \pm 0.05$ & $0.07 \pm 0.09$ & $0.10 \pm 0.01$ & $0.03 \pm 0.01$ & $1.65 \pm 0.11$ \\
\hline
\end{tabular}

COD - Chemical Oxygen Demand; RS - Reducing Sugar; TDS - Total Dissolved Solid; SP Soluble Protein; TSS - Total Suspended Solid.

Specific resistance to filtration (SRF) was determined to assess the dewaterability/filterability of the treated sludge. The filterability of treated sludge was significantly influenced by the fungal treatment as compared to untreated sample (Table 3 ). The filamentous fungi entrapped the solid particles of DWTP sludge and compressed sludge solids by filamentous mycelia, which modified the porosity structure of sludge cake, and accelerated the filtration process [9]. Fakhru'l-Razi et al. [8] has studied the filterability test of higher solids content of domestic wastewater sludge in shake flask using Aspergillus and Penicillium to evaluate its potentiality for bioconversion of wastewater sludge and has produced effective results.

\subsection{Solis state bioconversion process}

C/N ratio. The TOC and total Kjeldahl nitrogen $(\mathrm{TKN})$ ratio $(\mathrm{C} / \mathrm{N}$ ratio) decreased gradually in all situations over time of bioconversion periods (Table 4). In all cases, the treatments of mixed fungal culture influenced in decreasing (significantly at $\mathrm{P} \leq 0.05$ by LSD) the $\mathrm{C} / \mathrm{N}$ ratio than the control treatment. The obtained results of two different mixed cultures were roughly similar and insignificant in the solid state bioconversion of DWTP sludge. Comparatively sharp decreasing value was exhibited up to the period of 45 days mostly in all cases. The minimum 12.1 and 12.6 of the $\mathrm{C} / \mathrm{N}$ ratio were recorded for $\mathrm{RS}$ in compost by T/P and T/M, respectively after final days of treatment. In the case of the $\mathrm{SD}$, the lowest $\mathrm{C} / \mathrm{N}$ ratio were 16.0 and 16.7 which were achieved by $\mathrm{T} / \mathrm{P}$ and $\mathrm{T} / \mathrm{M}$, respectively in the process after the same period of treatment.

The $\mathrm{C} / \mathrm{N}$ ratio is an index traditionally used to evaluate the maturation of compost; the value cannot be used as an absolute indicator of compost maturation [3]. A C/N ratio $<20$ 
could be considered a satisfactory maturation level of compost [37] but a ratio $\leq 15$ is more preferable [23]. In the present study, the obtained results in CB implied the excellent maturation of compost. Fang et al. [3] recorded the final range of $\mathrm{C} / \mathrm{N}$ ratio of 17-19 over 100 days composting of sewage sludge, which was 25 initially in pile composting that did not have any microbial treatments. In 70 days composting program of soybean leaves, the final range of $\mathrm{C} / \mathrm{N}$ ratio 18-22 was achieved, when the initial ratio was 30 [38]. Mathur et al. [39] cited of $\mathrm{C} / \mathrm{N}$ ratio in the topic of 'determination of compost biomaturity' that the ideal $\mathrm{C} / \mathrm{N}$ ratio of mature compost is 10 , as in humus, hardly ever achieved by composting. In spite of this difficulty, they also remarked that the $\mathrm{C} / \mathrm{N}$ ratio up to 20 is acceptable for composts as long as they are biostable or mature. The $\mathrm{C} / \mathrm{N}$ ratio does generally decrease, except for an occasional increase due to loss of ammonia from some systems and reaches more or less a more stable level. Therefore, the $\mathrm{C} / \mathrm{N}$ ratio is a potential indicator of compost maturity but it cannot be used as a sole indicator of biomaturity for all types of composts [39].

Germination index. Germination index (GI \%) decreased gradually and attained to minimum at 30 days in both bulking materials (Table 5). The minimum value of GI for SD was 52.8 and $55.0 \%$ by T/M and T/P, respectively. Conversely, it was 33.4 and $39.6 \%$ for RS by T/P and T/M, respectively. In all situations, the values of GI increased to about $90 \%$ and above. At final harvest, the GI in SD was $\geq 100 \%$ in both mixed cultures. At last harvest, the highest level of GI was 99.0 and $122.2 \%$ were observed using bulking material of SD. On the other hand, for bulking material RS, the maximum $92.3 \%$ was recorded at last harvest (Table 5). Brassica napus seeds were used for GI, the profile of it clearly presented that the trend of GI started from around $100 \%$, then it gradually declined to $35-40 \%$ (most of the cases) at 30 days of SSB treatment of mixed fungal cultures and next it was increased around $100 \%$ and above at 60 to 75 days.

The GI (using Brasicca napus seeds) was the most sensitive parameter to evaluate the toxicity and degree of maturity status of compost [40]. The dropping of GI value in profile around 30 days of treatment might be the reason to the release of high concentration of ammonia and low molecular weight organic acids [3]. Excess of free ammonia is well known toxic organic chemical for seed germination and seedling growth. The GI level increased significantly $(\mathrm{P}<0.05)(122.2 \& 119.5 \%$ in SD by T/P \& T/M, respectively; 89.2 \& $92.3 \%$ in RS by T/P \& T/M, respectively) at 75 day, perhaps the relief of phytotoxins especially the ammonia volatilization and reduction of unstable organic acids. Higher phytotoxins, sources of unstable organic substances caused severe injuries of root systems [41]. Immature compost retarded plant growth due to nitrogen starvation, phytotoxicity of $\mathrm{NH}_{3}$ and some organic acids [39]. The GI of 50\% has been used as an indication of phytotoxin-free compost [40]. But in another report, when the GI value exceeded $80 \%$, then the sludge compost was considered as mature [42].

Glucosamine in water extract of compost. Glucosamine, an essential component in chitin of mycelial cell wall, is water-soluble sugar and stable component. It can be considered as a good parameter for indirect estimation of the nature of mycelial growth in solid substrate [43]. In another report, Roche et al. [44] found positive correlation between biomass and glucosamine content of fungi in solid state fermentation. In solid state fermentation of cranberry processing, higher mixed fungal mycelial growth was examined by estimation of glucosamine content [27]. 
Table 4: The changes of $\mathrm{C} / \mathrm{N}$ ratio during solid state bioconversion of domestic wastewater sludge using two mixed cultures.

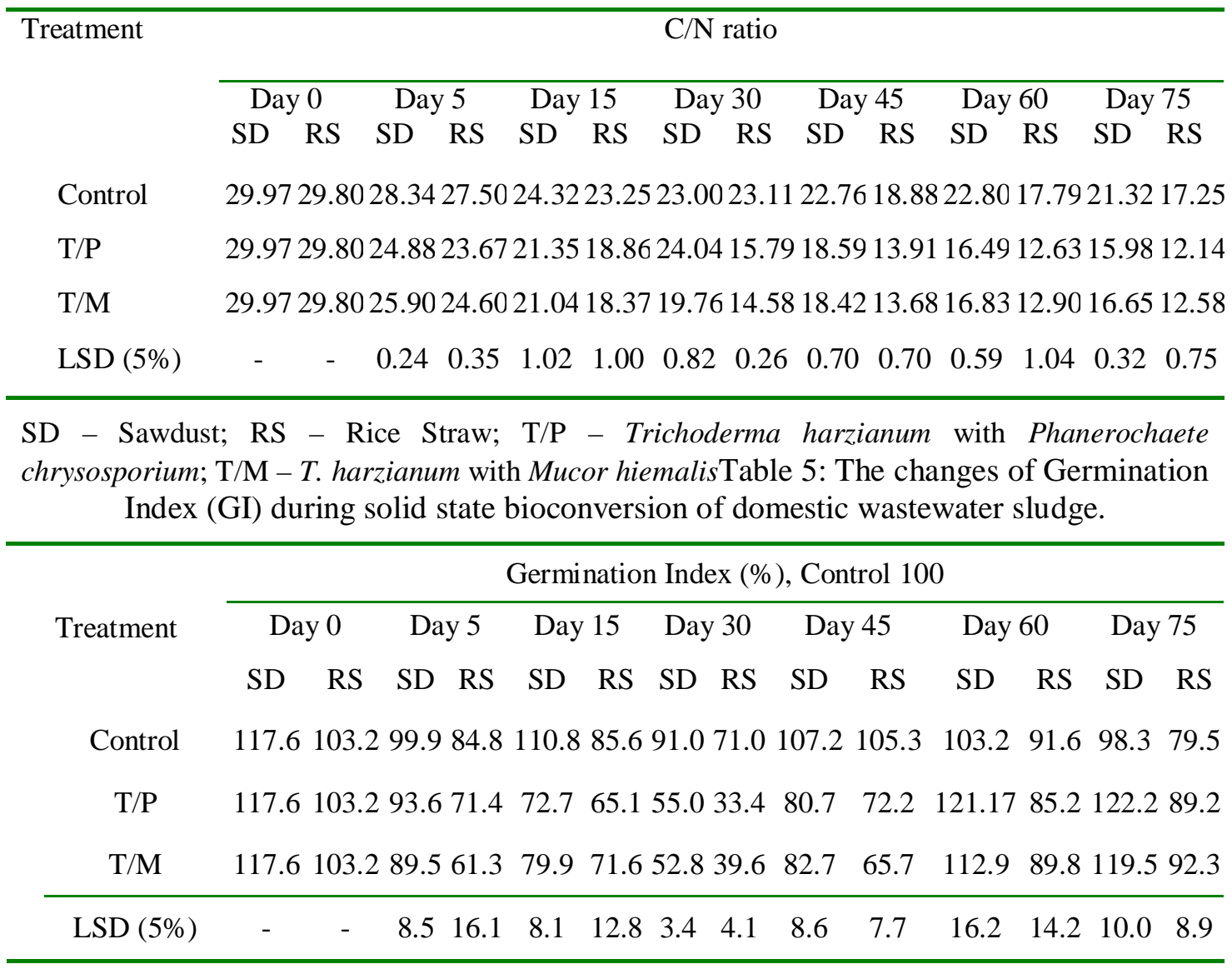

SD - Sawdust; RS - Rice Straw; T/P - Trichoderma harzianum with Phanerochaete chrysosporium; T/M - T. harzianum with Mucor hiemalis

Comparatively, higher results were achieved for RS than the SD (Table 6). It implied the higher growth of fungal mycelium occurred for RS. The results showed significantly higher trend of glucosamine profiles by fungal treatments than the control in all situations. But enhanced results were observed for RS by fungal treatments. Relatively poor results for SD implied the poor adaptation and growth of fungi might be due to the hard cell wall of wood than the rice straw. In cranberry processing under solid state culture, Zheng and Shetty [27] also explained the significant growth of fungi Trichoderma and Penicillium species by estimation of glucosamine and suggested as a good indicator of fungal biomass estimation in heterogeneous substrates. 
Table 6: Glucosamine during solid state bioconversion of DWTP sludge using two mixed cultures and bulking materials.

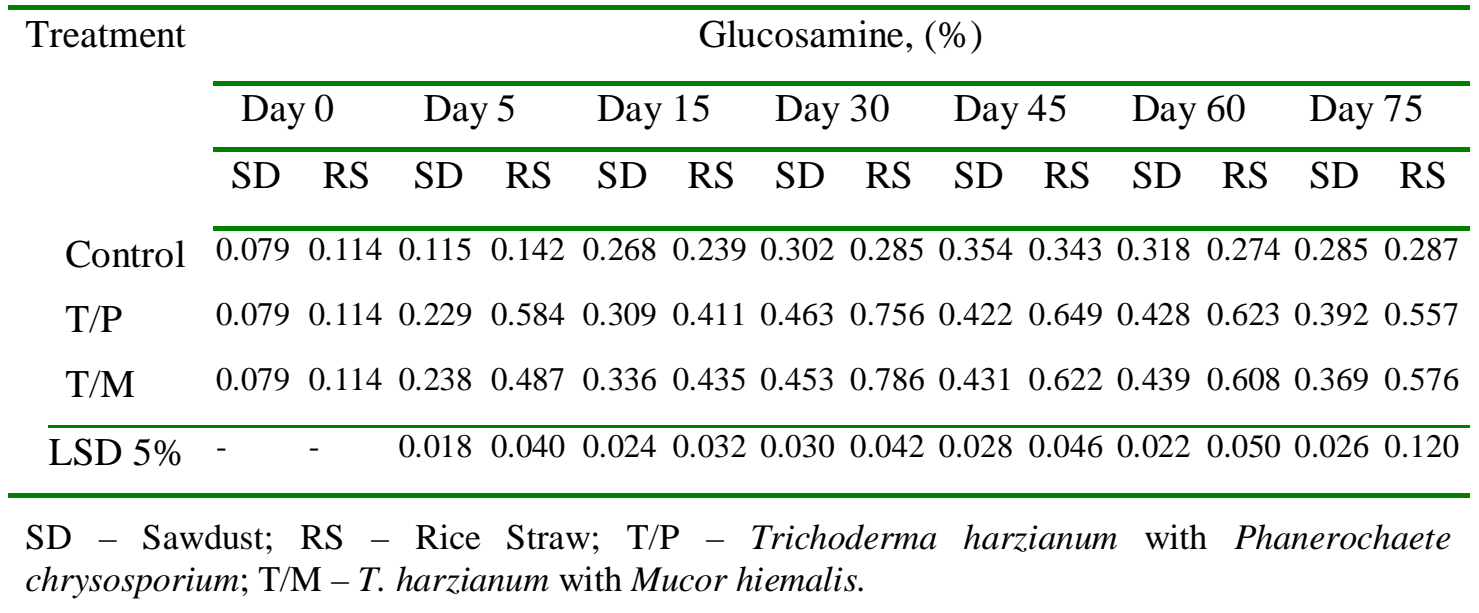

\subsection{Heavy metals and nutrients in compost of biosolids produced by SSB technique.}

The heavy metals status of compost produced by SSB of the DWTP sludge was not so changed by microbial treatment (Table 7). The analyzed record of heavy metals (in dry basis) in compost was lower than that of sludge (Table 4) due to dilution effect (i.e. composting is the mixture of equal half w/w of sludge and bulking materials). All heavy metals in Table 7 were about half or $50 \%$ of the amount present in sludge except $\mathrm{Mn}$ for RS. The reasons might be that the present study was carried out using sludge to bulking materials ratio of $1: 1(\mathrm{w} / \mathrm{w})$. Therefore, analysis of heavy metals from compost would be half than the sole sludge. Higher $\mathrm{Mn}$ in compost of RS might be the reason of bulking agent rice straw. Remediation of heavy metals is the limitation of bioconversion/bioremediation program, which was reported by Boopathy [45]. The acting microbes could assimilate some of the metals. But in chemicals analysis, which was not reflected because the metals absorbed by microbes were also contributing in results

Table 7. Heavy metals status of compost after 75 days of solid state bioconversion of IWK DWTP sludge using mixed fungal culture T. harzianum with P. chrysosporium 2094 (T/P) and T. harzianum with M. hiemalis (T/M).

\begin{tabular}{|c|c|c|c|c|c|c|c|c|c|c|c|c|}
\hline \multirow[t]{2}{*}{ Treatment } & \multicolumn{2}{|c|}{$\mathrm{Pb}$} & \multicolumn{2}{|c|}{$\mathrm{Ni}$} & \multicolumn{2}{|c|}{$\mathrm{Cu}$} & \multicolumn{2}{|c|}{$\mathrm{Mn}$} & \multicolumn{2}{|c|}{$\mathrm{Cd}$} & \multicolumn{2}{|c|}{$\mathrm{Zn}$} \\
\hline & SD & $\mathrm{RS}$ & $\mathrm{SD}$ & $\mathrm{RS}$ & SD & $\mathrm{RS}$ & SD & RS & SD & $\mathrm{RS}$ & SD & $\mathrm{RS}$ \\
\hline & \multicolumn{12}{|c|}{$\mathrm{mg} \mathrm{kg}^{-1}$} \\
\hline Control & 33.00 & 37.53 & 9.47 & 11.20 & 63.07 & 75.47 & 30.34 & 168.3 & 1.83 & 1.93 & 1120.0 & 1193.4 \\
\hline $\mathrm{T} / \mathrm{P}$ & 33.73 & 36.27 & 8.73 & 10.53 & 63.53 & 75.53 & 34.93 & 165.67 & 1.99 & 2.24 & 1130.0 & 1200.0 \\
\hline $\mathrm{T} / \mathrm{M}$ & 32.67 & 31.87 & 9.07 & 10.27 & 58.47 & 74.53 & 35.53 & 163.80 & 1.75 & 2.02 & 1073.4 & 1160.0 \\
\hline LSD $5 \%$ & 1.7 & & 1. & 6 & 5.2 & & 11. & 81 & 0.2 & & 61. & \\
\hline
\end{tabular}

SD - Sawdust RS - Rice Straw; T/P - Trichoderma harzianum with Phanerochaete chrysosporium; T/M.- T. harzianum with Mucor hiemalis, Chemical analysis for heavy metals estimation was done in dry basis. 
It was not possible to separate out the acting microbes from compost before chemical analysis. The heavy metals were significantly changed between composts of RS (i.e, CRS) and SD (i.e, CSD) due to influence of bulking materials (Table 7). The higher amount was achieved in rice straw. Furthermore, the amounts of heavy metals present in composts (CRS and CSD) are quite low than the standard limits of several countries except for chromium (Cr) and zinc ( $\mathrm{Zn})$ in some cases (Table 8). On an average the amount of heavy metals present in composts (CRS and CSD) are 30 times lower compare to the level that have recommended to be applied for crop production by USA in compost of MSW [46]. Indah Water Konsortium (IWK) is dealing with only urban sewage sludge and free from industrial wastewater. Therefore, it contains comparatively lower amount of heavy metals. Ishak et al. [47] reported that significant higher amount of $\mathrm{Cd}$ and $\mathrm{Zn}$ was disseminated in soil after direct application of the IWK wastewater sludge for corn cultivation. Contamination of $\mathrm{Cu}, \mathrm{Cr}$, and $\mathrm{Cd}$ are mainly concerned with industrial wastewater but $\mathrm{Zn}$ and $\mathrm{Pb}$ are mainly from domestic wastewater [48]. It might be the reason of higher amount of $\mathrm{Zn}$ in IWK sludge (Table 8).

Table 8: Nutritional status of composts from IWK DWTP sludge. Standard limits of heavy metals of MSW composts in some countries [46, 51] and typical level in soil [52].

\begin{tabular}{|c|c|c|c|c|c|c|c|}
\hline \multirow[t]{2}{*}{ Parameters } & \multicolumn{2}{|c|}{ Compost $^{\mathrm{a}}$} & \multirow[t]{2}{*}{ USA } & \multirow[t]{2}{*}{$\mathrm{EC}$} & \multirow[t]{2}{*}{ Australia } & \multirow[t]{2}{*}{ China } & \multirow{2}{*}{$\begin{array}{l}\text { Typical } \\
\text { value in soi }\end{array}$} \\
\hline & CRS & CSD & & & & & \\
\hline Moisture (\%) & 69.87 & 66.88 & - & - & $25-35$ & $25-35$ & - \\
\hline $\mathrm{pH}$ & 5.27 & 5.15 & - & - & $7.0-8.5$ & $6.5-8.5$ & 5.0 \\
\hline $\mathrm{C} / \mathrm{N}$ ratio & 12.11 & 15.60 & - & - & - & - & 11 \\
\hline $\mathrm{EC}\left(\mathrm{dS} \mathrm{m} \mathrm{m}^{-1}\right)$ & 1.49 & 0.35 & - & - & - & - & - \\
\hline $\mathrm{BD}\left(\mathrm{kg} \mathrm{m}^{-3}\right)$ & 1099.22 & 953.26 & - & - & - & - & 1300 \\
\hline $\mathrm{N}(\%)$ & 3.10 & 2.87 & - & 0.6 & $0.5-1.5$ & $\geq 0.5$ & 0.4 \\
\hline $\mathrm{P}(\%)$ & 0.84 & 0.62 & - & 0.5 & $0.4-0.8$ & $\geq 0.3$ & $0.05-0.2$ \\
\hline $\mathrm{K}(\%)$ & 3.13 & 0.25 & - & 0.3 & $0.3-1.0$ & $\geq 1.0$ & $0.04-3.0$ \\
\hline $\mathrm{Ca}(\%)$ & 0.10 & 0.05 & - & - & - & - & $0.7-50$ \\
\hline $\operatorname{Mg}(\%)$ & 0.21 & 0.05 & - & - & - & - & $0.06-6.0$ \\
\hline $\mathrm{Pb}\left(\mathrm{mg} \mathrm{kg}^{-1}\right)$ & 36.27 & 33.73 & 300 & 750 & $200-900$ & $\geq 100$ & $2-100$ \\
\hline $\mathrm{Ni}\left(\mathrm{mg} \mathrm{kg}^{-1}\right)$ & 10.53 & 8.73 & 420 & 50 & $30-200$ & - & - \\
\hline $\mathrm{Cd}\left(\mathrm{mg} \mathrm{kg}^{-1}\right)$ & 2.24 & 1.99 & 39 & 5 & $1-6$ & $\geq 3$ & $0.01-7.0$ \\
\hline $\mathrm{Cr}\left(\mathrm{mg} \mathrm{kg}^{-1}\right)$ & 508.33 & 450.0 & 1200 & 150 & $50-300$ & $\geq 300$ & $5-3000$ \\
\hline $\mathrm{Cu}\left(\mathrm{mg} \mathrm{kg}^{-1}\right)$ & 75.53 & 63.53 & 1500 & 300 & 1000 & - & $2-100$ \\
\hline $\operatorname{Mn}\left(\mathrm{mg} \mathrm{kg}^{-1}\right)$ & 165.67 & 34.93 & - & - & $500-1200$ & - & $100-4000$ \\
\hline $\mathrm{Zn}\left(\mathrm{mg} \mathrm{kg}^{-1}\right)$ & 1200.0 & 1130.0 & 2800 & 1000 & $300-1500$ & - & $10-300$ \\
\hline $\mathrm{Na}\left(\mathrm{mg} \mathrm{kg}^{-1}\right)$ & 436.50 & 1364.5 & - & - & - & - & $400-30000$ \\
\hline $\mathrm{Fe}\left(\mathrm{mg} \mathrm{kg}^{-1}\right)$ & 9200 & 8066 & - & - & - & - & - \\
\hline
\end{tabular}

${ }^{a}$ CRS: Compost -rice straw, CSD: Compost -sawdust. Both prepared with mixed fungi $T$. harzianum and $P$. chrysosporium 2094 inoculation by SSB process. All nutrients were analyzed as dry basis. 
Moreover, in the present study, the end product (compost) of SSB of DWTP sludge achieved the suitable characteristics of stable matured composts in compared to others in relatively shortest period of time (Table 9). The composting duration may significantly reduce if the process is operated in mechanized control condition. It contains more or less all nutrients (Table 8). It can supplement the trace elements to the soil in sufficient amount for better plant growth. The compost of CRS possessed higher nutrients levels than the CSD i.e. all major nutrients are higher in CRS than the CSD (Table 8).

Table 9: Comparative study of composts of IWK DWTP sludge by SSB process with others*.

\begin{tabular}{|c|c|c|c|c|c|}
\hline $\begin{array}{l}\text { Compost quality } \\
\text { characteristics }\end{array}$ & $\begin{array}{l}\text { Siegfried } \\
\text { Agro and } \\
\text { AsiaGreen }\end{array}$ & $\begin{array}{l}\text { Nutri } \\
\text { Plus }\end{array}$ & $\begin{array}{l}\text { Compost } \\
\text { (Negro et } \text { al., 1999) }\end{array}$ & CRS & CSD \\
\hline Dry substance (\% DS) & $40-60$ & 55 & 62 & 47.66 & 46.95 \\
\hline $\mathrm{pH}$ value & $7-8$ & - & 5.3 & 5.27 & 5.15 \\
\hline $\mathrm{EC}(\mathrm{dS} / \mathrm{m})$ & $0.5-1.5$ & - & 2.98 & 1.49 & 0.35 \\
\hline Organic matter (\% OM) & - & $16-29$ & 75 & 31.67 & 37.37 \\
\hline Nitrogen $(\%)$ & $0.6-1.3$ & 0.9 & 3.0 & 1.48 & 1.38 \\
\hline Phosphorous (\%) & $0.15-0.62$ & - & 0.88 & 0.40 & 0.29 \\
\hline Potassium (\%) & $0.37-1.49$ & - & 0.57 & 1.49 & 0.12 \\
\hline Calcium (\%) & $2.48-9.94$ & 1.3 & 0.005 & 0.05 & 0.02 \\
\hline Magnesium (\%) & $0.4-1.6$ & - & 0.45 & 0.10 & 0.02 \\
\hline TOC $(\%)$ & - & - & 39 & 17.93 & 21.53 \\
\hline $\mathrm{C} / \mathrm{N}$ ratio & $12-18$ & - & 13 & 12.11 & 15.60 \\
\hline Bulk density $\left(\mathrm{kg} \mathrm{m}^{-3}\right)$ & - & - & - & 1099.22 & 953.26 \\
\hline Germination index $(\%)$ & $80-94$ & - & $>50$ & 90 & 122 \\
\hline Weight loss (\%) & - & - & - & 18.29 & 7.57 \\
\hline Duration (days) & $56-70$ & - & $>365$ & $50-60$ & $50-60$ \\
\hline Odor status & - & free & - & odor free & odor free \\
\hline Out look & - & - & - & good & good \\
\hline $\begin{array}{l}\mathrm{N}(\%) \text { supplement in crop } \\
\text { production }\end{array}$ & - & - & - & $50 \%$ & $50 \%$ \\
\hline Weed status & - & free & - & free & free \\
\hline
\end{tabular}

${ }^{*}$ All chemical analysis was done as wet basis. Both composts (CRS: Compost of biosolids with rice straw and CSD: Compost of biosolids with sawdust) were produced in solid state bioconversion using filamentous mixed fungal culture $T$. harzianum with $P$. chrysosporium 2094.

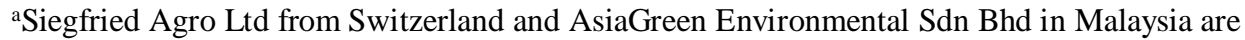
commercially producing composts in joined venture and recommended the optimal level of characteristics of matured quality compost.

b Nutri Plus is compost produced commercially by Edmonton Composting Facility, Canada from Municipal Solid Waste and Sewage biosolids.

${ }^{\mathrm{c}}$ Compost produced from Sewage sludge with Sorghum bagasse, the chemical analyzed was done in dry basis 


\section{CONCLUSION}

In the present study, LSB process increased the biosolids accumulation, moreover it enhanced nutrients and dewaterability, and minimized soluble and insoluble organic/inorganic substances in supernatant. The results also revealed that the SSB process efficiently and effectively converted the treated biosolids from LSB into compost and retained high nutrient values compared to other composts. The integrated processes of LSB and SSB may show a complete solution of higher concentration of wastewater sludge $(4 \% \mathrm{w} / \mathrm{w})$ to value added products (compost) by enhancing the biosolids accumulation, bioseparation and biodegradation. This study may enhance the planning of sludge management strategies using this integrated processes in future research, solutions and applications.

\section{ACKNOWLEDGEMENT}

The authors are grateful to the Department of Chemical and Environmental Engineering, Universiti Putra Malaysia (UPM) for their kind support and IWK for their research grant as well as providing the sludge sample during this study.

\section{REFERENCES}

[1] O. Lorain, P. Thiebaud, E. Badorc, Y. Aurelli, "Potential of Freezing in Wastewater Treatment: Soluble Pollutant Applications”, Water Res. Vol. 35(2), pp. 541-547. 2001

[2] M. Oudeh, M. Khan, J. Scullion, "Plant Accumulation of Potentially Toxic Elements in Sewage Sludge as Affected by Soil Organic Matter Level and Mycorrhizal Fungi", Environ. Poll, Vol. 116, pp. 293-300, 2002.

[3] M. Fang, J. W. C. Wong, G. X. Li, M. H. Wong, "Changes in Biological Parameters During Co-Composting of Sewage Sludge and Coal Ash Residues", Bioresource Technol, Vol. 64, pp. 55-61, 1998.

[4] M. Z. Alam, A. Fakhru'l-Razi, A. H. Molla, P. K. Roychoudhury, "Treatment of Wastewater Sludge by Liquid State Bioconversion Process", J. Environ. Sci. Health, Vol. A36 (7), pp. 1237-1243, 2001.

[5] A. H. Molla, "Solid State Bioconversion of Domestic Wastewater Treatment Plant Sludge into Compost by Screened Filamentous Fungi", Ph. D. thesis. Faculty of Engineering, Universiti Putra Malaysia (UPM), Malaysia, 2002.

[6] A. Fakhru'l-Razi, M. Z. Alam, A. Idris, S. Abd-Aziz, A. H. Molla, "Filamentous Fungi in Indah Water Konsortium (IWK) Sewage Treatment Plant for Biological Treatment of Domestic Wastewater Sludge”. J. Environ. Sci. Health, Vol. A37 (3), pp. 309-320, 2002.

[7] M. Z. Alam, A. Fakhru'l-Razi, "Enhanced Settleability and Dewaterability of Fungal Treated Domestic Wastewater Sludge By Liquid State Bioconversion Process", Water Res. Vol. 37, pp. 1118-1124, 2003.

[8] A. Fakhru'l-Razi, M. Z. Alam, A. Idris, S. Abd-Aziz, A. H. Molla, "Domestic Wastewater Biosolids Accumulation by Liquid State Bioconversion Process for Rapid Composting”, J. Environ. Sci. Health, Vol. A37 (8), pp. 1533-1543, 2002. 
[9] M. Z. Alam, A. Fakhru'l-Razi, "Biosolids Accumulation and Biodegradation of Domestic Wastewater Treatment Plant Sludge by Developed Liquid State Bioconversion Process using a Batch Fermenter", Water Res. Vol. 37, pp. 3569-3578. 2003.

[10] ILBS (International Law Book Services), "Laws of Malaysia. In Environmental Quality Act 1974 (act 127) \& Subsidiary Legislation", International Law Book Services (ILBS), Kuala Lumpur, Malaysia, pp.121, 1999.

[11] R. P. Tengerdy, "Solid State Fermentation of Lignocelluloses. In Solid Substrate Cultivation”, Eds. H. W. Doelle, D. A. Mitchell, and C. E. Rolz, pp. 269-282, Elservier Science Ltd., London, 1992.

[12] X.Yang, H. Chen, H. Gao, Z. Li, "Bioconversion of Corn Straw by Coupling Ensiling and Solid-State Fermentation”, Bioresource Technol. Vol. 78, pp. 227-280, 2001.

[13] M. Raimbault, "General and Microbiological Aspects of Solid Substrate Fermentation", Electronic J. Biotechnol. Vol. 1(3), pp. 1-15, 1998.

[14] M. Z. Alam, A. Fakhru'l-Razi, A. H. Molla, "Evaluation of Fungal Potentiality for Bioconversion of Domestic Wastewater Sludge”, J. Environ. Sci, Vol. 16, 132-137, 2004.

[15] M. Z. Alam, A. Fakhru'l-Razi, S. Abd-Aziz, , Abul H. Molla, "Optimization of Compatible Mixed Cultures for Liquid State Bioconversion of Municipal Wastewater Sludge", Water, Air and Soil Pollution, Vol. 149, pp. 113-126, 2003 b.

[16] A.H. Molla, A. Fakhru'l-Razi, S. Abd-Aziz, M.M. Hanafi, P.K. Roychoudhury, M.Z.Alam, "A Potential Resource for Bioconversion of Domestic Wastewater Sludge”, Bioresource Technol, Vol. 85(3), pp. 263-272, 2002.

[17] A.H. Molla, A. Fakhru'l-Razi, S. Abd-Aziz, M.M. Hanafi, M.Z. Alam, “In-Vitro Compatibility Evaluation of Fungal Mixed Culture for Bioconversion of Domestic Wastewater Sludge", World J. Microbiol. Biotechnol, Vol. 17(9), pp. 849-856, 2001.

[18] A.H. Molla, A. Fakhru'l-Razi, M.M. Hanafi, S. Abd.-Aziz, M.Z. Alam, "Potential Non-Phytopathogenic Filamentous Fungi for Bioconversion of Domestic Wastewater Sludge”, J. Environ. Sci. Health A Vol. 37(8), pp. 1495-1507, 2002.

[19] M. Z. Alam, A. Fakhru'l-Razi, A. H. Molla, "Optimization of Liquid State Bioconversion Process for Microbial Treatment of Domestic Wastewater Sludge”, J. Environ. Eng. Sci. Vol. 2, pp. 299-306, 2003.

[20] APHA, "Standard Methods for the Examination of Water And Wastewater", $17^{\text {th }}$ edition, American Public Health Association, Washington, DC. 1989.

[21] O.H. Lowry, N.J. Rosebrough, A.L. Farr, R. J. Randall, "Protein Measurement with the Folin Phenol Reagent”, J. Biol. Chem. Vol. 193, pp. 265-275, 1951.

[22] G.L. Miller, "Use of Dinitrosalicylic Acid Reagent for Determination of Reducing Sugar", Anal. Chem, Vol. 31, pp. 426-428, 1959.

[23] A.F. Navarro, J. Cegarra, A. Roig, D. Garcia, "Relationships between Organic Matter and Carbon Contents Of Organic Wastes", Bioresource Technol. Vol. 44, pp. 203-207, 1993.

[24] J. M. Bremner, "Determination of Nitrogen in Soil by the Kjeldahl Method", J. Agric. Sci, Vol. 55, pp. 11-31, 1960.

[25] A. Cottonie, G. Velghe, M. Verloo, L. Kiekens, "Analytical Methods for Plants and Soils", Laboratory of Analytical and Agrochemistry, State Univ., Ghent-Belgium, pp. 29, 1979.

[26] P. C. Carman, "Fundamental Principals of Industrial Filtration (A Critical Review Of Present Knowledge)", Trans. Insts. Chemical Engineers. Vol. 16, pp. 168, 1977. 
[27] Z. Zheng, K. Shetty, "Cranberry Processing Waste for Solid State Fungal Inoculant Production", Process Biochem, Vol. 33(3), pp. 323-329, 1998.

[28] F. Zucconi, M. Forte, A. Monaco, M. de Bertoldi, "Biological Evaluation of Compost Maturity", BioCycle, Vol. (7\&8), pp. 27-29, 1981a

[29] MST (Michigan State University), "User's Guide to MSAT-C", Michigan State University, East Lasing, MI, 1989.

[30] B. Jin, J. Van Leeuwen, Q. Yu, B. Patel, "Screening and Selection of Microfungi for Microbial Biomass Protein Production and Water Reclamation from Starch Processing Wastewater", J. Chem. Technol. Biotechnol, Vol. 74, pp. 106-110, 1999.

[31] A. Robles, R. Lucas, G. Alvarez de Cienfuegos, A. Galvez, "Biomass Production and Detoxification of Wastewaters from the Olive Oil Industry by Strains of Penicillium Isolated from Wastewater Disposal Ponds", Bioresource Technol, Vol. 74, pp. 217-221, 2000.

[32] M. Soumaré, A. Demeyer, F.M.G. Tack, M.G. Verloo, "Chemical Characteristics of Malian and Belgian Solid Waste Composts”, Bioresource Technol, Vol. 81, pp. 97-101, 2002.

[33] J.J. Thambirajah, M.D. Zulkali, M.A. Hashim, "Microbiological and Biochemical Changes during the Composting of Oil Palm Empty-Fruit Bunches-Effect of Nitrogen Supplementation on the Substrate", Bioresource Technol. Vol. 52 (2), pp. 133-144, 1995.

[34] E. Valdman, L. Erijman, F.L.P. Pessoa, S.G.F. Leite, "Continuous Biosorption of $\mathrm{Cu}$ and $\mathrm{Zn}$ by Immobilized Waste Biomass Sargassum Sp.”, Process Biochem. Vol. 36, pp. 869-873, 2001.

[35] M. S. Price, J. J. Classen, G. A. Payne, "Aspergillus niger Absorbs Copper and Zinc from Swine Wastewater", Bioresource Technol, Vol. 77, pp. 41-49, 2001.

[36] G. Wen, J.P. Winert, R.P. Voroney, T.E. Bates, "Potassium Availability with Application of Sewage Sludge, and Sludge and Manure Compost in the Field Experiments", Nutr. Cyc. Agroecosys. Vol. 47, pp. 233-241, 1997.

[37] I. van Heerden, C. Cronjé, S. H. Swart, J. M. Kotzé, "Microbial Chemical and Physical Aspects of Citrus Waste Composting”, Bioresource Technol, Vol. 81, pp. 71-76, 2002.

[38] J.W.C. Wong, K.F. Mak, N.W. Chan, A. Lam, M Fang, L.X. Zhou, Q.T. Wu, X. D. Liao, "Co-composting of Soybean Residues and Leaves in Hong Kong", Bioresource Technol, Vol. 76, pp. 99-106, 2001.

[39] S.P. Mathur, G. Owen, H. Dinel, M Schnitzer, "Determination of Compost Biomaturity. I. Literature Review”, Biol. Agril. Hort, Vol. 10, pp. 65-85, 1993.

[40] F. Zucconi, A. Monaco, M. Forte, "Phytotoxins during the Stabilization of Organic Matter. Composting of Agricultural and Other Wastes", Ed. J. K. R. Gasser, pp 7385. Elsevier Applied Science Publishers, 1984.

[41] F. Zucconi, A Pera, M. Fote, "Evaluation Toxicity of Immature Compost. BioCycle", Vol. (3 \& 4), pp. 54-57, 1981 b.

[42] H. Xu, "Studies on aerated static pile on sewage composting. M. Sc. Dissertation", Research Center for Eco-Environmental Sciences, Chinese Academy of Sciences, Beijing, 1999.

[43] C. Desgranges, C. Vergoignan, M. Georges, A. Durand, "Biomass Estimation in Solid-State Fermentation. I. Manual Biochemical Methods", Appl. Microbiol. Biotechnol, Vol. 35, pp. 200-205, 1991. 
[44] N. Roche, A. Venague, C. Desgranges, A. Durand, "Use of Chitin Measurement to Estimate Fungal Biomass in Solid State Fermentation", Biotechnol. Advan, Vol. 11, pp. 677-683. 1993.

[45] R. Boopathy, "Factors Limiting Bioremediation Technologies", Bioresource Technol, Vol. 74, pp. 63-67, 2000.

[46] Y.-S. Wei, Y.-B. Fan, M.-J. Wang, J.-S. Wang, "Composting and Compost Application in China", Resource, Conservat. Recycl, Vol. 30, pp. 277-300, 2000.

[47] C.F. Ishak, R.A. Bakar, H.M. Saud, T.L. Abdullah, "Application of Sewage Sludge from Indah Water Treatment Plants", Agro-Search, Vol. 6(1), pp. 14-19, 1999.

[48] L. Kuai, F. Doulami, W. Verstraete, "Sludge Treatment and Reuse as Soil Conditioner for Small Rural Communities", Bioresource Technol. 73, 213-219. 2000.

[49] M. Fang, J. W. C. Wong, K. K. Ma, M. H. Wong, "Co-Composting of Sewage Sludge and Coal Fly Ash: Nutrient Transformations", Bioresource Technol, Vol. 67, pp. 19-24, 1999.

[50] M. -H. Charest, C. J. Beauchamp, "Composting of De-Inking Paper Sludge with Poultry Manure at Three Nitrogen Levels Using Mechanical Turning: Behaviour of PhysicoChemical Parameters", Bioresource Technol, Vol. 81, pp. 7-17, 2002.

[51] X.T. He, T. J. Logan, S. J. Traina, "Physical and Chemical Characteristics of Selected U. S. Municipal Solid Waste Composts", J. Environ. Qual, Vol. 24, pp. 543-552, 1995.

[52] D. C. Adriano, A. L. Page, A. A. Elseewi, A. C. Chang, I. Straughan, "Utilization and Disposal of Fly Ash and Other Coal Residues in Terrestrial Ecosystem: A Review". Journal of Environmental Quality, Vol 9, pp. 333-334, 1980. 